\title{
Oligo-carrageenan kappa increases NADPH, ascorbate and glutathione syntheses and TRR/TRX activities enhancing photosynthesis, basal metabolism, and growth in Eucalyptus trees
}

\author{
Alberto González, Fabiola Moenne, Melissa Gómez, Claudio A. Sáez, Rodrigo A. Contreras and \\ Alejandra Moenne*
}

Marine Biotechnology Laboratory, Department of Biology, Faculty of Chemistry and Biology, University of Santiago of Chile, Santiago, Chile

\section{Edited by:}

Chandrashekhar Pralhad Joshi, Michigan Technological University, USA

Reviewed by:

Gong-yin Ye, Zhejiang University,

China

Ahmad Parveez Ghulam Kadir,

Malaysian Palm Oil Board, Malaysia

*Correspondence:

Alejandra Moenne, Faculty of

Chemistry and Biology, University of

Santiago of Chile,

9170022 Santiago, Chile

e-mail: alejandra.moenne@usach.cl
In order to analyze the effect of OC kappa in redox status, photosynthesis, basal metabolism and growth in Eucalyptus globulus, trees were treated with water (control), with OC kappa at $1 \mathrm{mg} \mathrm{mL}^{-1}$, or treated with inhibitors of $\mathrm{NAD}(\mathrm{P}) \mathrm{H}$, ascorbate (ASC), and glutathione (GSH) syntheses and thioredoxin reductase (TRR) activity, CHS-828, lycorine, buthionine sulfoximine (BSO), and auranofin, respectively, and with OC kappa, and cultivated for 4 months. Treatment with OC kappa induced an increase in NADPH, ASC, and GSH syntheses, TRR and thioredoxin (TRX) activities, photosynthesis, growth and activities of basal metabolism enzymes such as rubisco, glutamine synthetase (GlnS), adenosine 5'-phosphosulfate reductase (APR), involved in C, N, and S assimilation, respectively, Krebs cycle and purine/pyrimidine synthesis enzymes. Treatment with inhibitors and OC kappa showed that increases in ASC, GSH, and TRR/TRX enhanced NADPH synthesis, increases in NADPH and TRR/TRX enhanced ASC and GSH syntheses, and only the increase in NADPH enhanced TRR/TRX activities. In addition, the increase in NADPH, ASC, GSH, and TRR/TRX enhanced photosynthesis and growth. Moreover, the increase in NADPH, ASC and TRR/TRX enhanced activities of rubisco, Krebs cycle, and purine/pyrimidine synthesis enzymes, the increase in GSH, NADPH, and TRR/TRX enhanced APR activity, and the increase in NADPH and TRR/TRX enhanced GInS activity. Thus, OC kappa increases NADPH, ASC, and GSH syntheses leading to a more reducing redox status, the increase in NADPH, ASC, GSH syntheses, and TRR/TRX activities are cross-talking events leading to activation of photosynthesis, basal metabolism, and growth in Eucalyptus trees.

Keywords: ascorbate, basal metabolism, Eucalyptus globulus, glutathione, NADPH, redox status, thioredoxin reductase, thioredoxin

\section{INTRODUCTION}

The redox status in plants is mainly determined by the levels of $\mathrm{NADPH}, \mathrm{NADH}$, ascorbate (ASC), and reduced glutathione (GSH) as well as by the activities of antioxidant enzymes using NADPH, NADH, ASC, and GSH as substrates (Foyer and Noctor, 2011). NADH/NADPH are essential reducing compounds for plant viability since the disruption of the unique gene encoding nicotinamide mononucleotide adenylyl transferase (NMNAT), a key regulatory enzyme of NAD synthesis, was lethal in Arabidopsis thaliana (Hashida et al., 2009). In addition, the heterozygous mutant of nmta gene showed shorter siliques with lower seed set indicating that $\mathrm{NAD}(\mathrm{P}) \mathrm{H}$ content may be involved in regulating growth and development (Hashida et al., 2007). ASC is also an essential molecule for plant viability since Arabidopsis mutants completely deficient in ASC were observed to be seedling lethal (Dowdle et al., 2007). In addition, it has been shown that ASC is essential for transition from G1 to $S$ phase as recorded in tobacco cells cultured in vitro as well as in cells of the quiescent center in onion roots (Liso et al., 1988; De Pinto et al., 1999). Furthermore, ASC may regulate growth since tomato mutants having a lower activity of L-galactonolactone dehydrogenase (GLDH), the last and regulatory enzyme for ASC synthesis, showed a decrease in growth rates, and in leaves and fruit sizes (Alhagdow et al., 2007). In addition, GSH is essential for plant viability since mutants deficient in GSH synthesis were observed to be embryo lethal (Cairns et al., 2006). Moreover, GSH was observed to be necessary for transition from G1 to S phase in tobacco cells cultured in vitro, and for cell division in the apical meristem of A. thaliana roots (Vernoux et al., 2000). Furthermore, GSH may also regulate photosynthesis and growth since cucumber plant treated with a brassinosteroid showed an increased in GSH/GSSG ratios followed by an increased photosynthesis and $\mathrm{C}$ assimilation (Jiang et al., 2012). In addition, A. thaliana individuals having a mutation in the gene encoding for $\gamma$-glutamylcysteine synthase 
$(\gamma$-GCS), the first and regulatory enzyme involved in GSH synthesis, and in NADPH-dependent thioredoxin reductases (TRRs) showed smaller size shoots and roots and a decrease in auxin levels, and in the expression of genes encoding auxin transporters (Bashandi et al., 2010).

In addition, plant growth is also regulated by the coordinated assimilation of carbon $(\mathrm{C})$, nitrogen $(\mathrm{N})$, and sulfur $(\mathrm{S})$, which are reductive light-dependent processes (Kopriva et al., 1999, 2002; Lillo, 2008; Kraiser et al., 2011; Takahashi et al., 2011). Carbon assimilation is partly subject to photosynthesis and activities of Calvin-Benson cycle enzymes, mainly by ribulose 1,5-biphosphate carboxylase/oxygenase (rubisco) that catalyzes the limiting reaction responsible of reducing atmospheric $\mathrm{CO}_{2}$ into a three-carbon sugar (Kopriva et al., 2002). Nitrogen assimilation requires the uptake of nitrate from the soil, which is reduced to nitrite and then to ammonium in the shoots where, in turn, takes part of the aminoacids glutamine and glutamate (Kraiser et al., 2011). The latter aminoacids are synthesized by the enzymes glutamine synthetase (GlnS) and glutamate dehydrogenase $(\mathrm{GDH})$, respectively, and GlnS activity is the limiting reaction. On the other hand, sulfur assimilation involves sulfate uptake from the soil which is reduced to sulfite and then to sulfide in the shoots where, in turn, takes part of the aminoacid cysteine after an $\mathrm{O}$-acetylserine thiol-lyase catalyzed reaction (O-ASTL) (Takahashi et al., 2011). Moreover, the reduction of adenosine $5^{\prime}$-phosphosulfate (APS) to sulfite is mediated by the enzyme adenosine $5^{\prime}$-phosphosulfate reductase (APR), which is the limiting reaction in sulfur assimilation (Vauclaire et al., 2002).

In addition, it is well known that NADPH levels are involved in regulating basal metabolism through TRRs/thioredoxins (TRXs) system, since TRR uses NADPH as substrate, TRRs reduce TRXs, and TRXs reduce disulfide residues of many key metabolic enzymes inducing their activation and, only in few cases, their inactivation. Moreover, TRR/TRX activities have been shown to influence photosynthesis, $\mathrm{C}, \mathrm{N}$ and $\mathrm{S}$ assimilation and growth (Gelhaye et al., 2005; Montrichard et al., 2009). In particular, TRXs interact with the small and the large subunits of rubisco and rubisco activase (RAC), an ATP-dependent chaperone that removes sugar-phosphates from rubisco's active site (Motohashi et al., 2001; Gelhaye et al., 2005). In addition, functional assays have demonstrated that TRXs activate RAC which, in turn, increase rubisco activity in A. thaliana (Zhang and Portis, 1999). Furthermore, TRXs bind to GlnS, the regulatory enzyme of $\mathrm{N}$ assimilation (Yamazaki et al., 2004), and mediate the increase in GlnS and glutamate synthase (GluS) activities in the green microalga Chlorella sorokiniana (Tischner and Schmidt, 1982). Until now, there is no evidence indicating that TRXs are directly involved in the activation of APR and O-ASTL, but it has been recently shown that TRXs activate a cyclophilin, which is a molecular chaperone with peptidyl prolyl isomerase activity, that activates O-ASTL in A. thaliana (Dominguez-Solís et al., 2008). Until now, there is no evidence demonstrating that TRR/TRX system is involved in the regulation of $\mathrm{NAD}(\mathrm{P}) \mathrm{H}$, ASC and/or GSH syntheses.

In previous work, we determined that oligo-carrageenans (OCs), obtained by acid depolymerization of carrageenans extracted from marine red algae, induced an increase in plant growth (González et al., 2013a) as well as in protection against pathogens (Vera et al., 2011). OCs kappa, lambda and iota are constituted by around 20 units of sulfated galactose linked by alternate $\beta$-1,4- and $\alpha$-1,3-glycosidic bonds with sulfate groups located in positions 2,4 , and 6 of the galactose ring, with or without anhydrogalactose units (for models see Vera et al., 2011). In tobacco plants, stimulation of growth is due to an increase in net photosynthesis, basal metabolism and cell division, mainly in response to OC kappa and iota (Castro et al., 2012). In tobacco plants, OCs increased $\mathrm{CO}_{2}$ incorporation, stomatal conductance, PSII efficiency, chlorophyll $a$ and $b$ content, and rubisco activity indicating an increase in net photosynthesis and $\mathrm{C}$ assimilation (Castro et al., 2012). In addition, activities of basal metabolism enzymes producing $\mathrm{NAD}(\mathrm{P}) \mathrm{H}$ were also enhanced in tobacco plants suggesting that the content of reducing power $[\mathrm{NAD}(\mathrm{P}) \mathrm{H}]$ may also be increased (Castro et al., 2012). Moreover, the level of transcripts encoding cyclins $\mathrm{A}$ and $\mathrm{D}$ (cycA and $\mathrm{cycD}$, respectively), and cyclin-dependent kinases A and B (CDKA and CDKB, respectively), were also increased suggesting a stimulation of cell cycle and cell division (Castro et al., 2012). Furthermore, treatment with OCs increased the level of ASC, but not GSH, which may help the observed increase in cell division in tobacco plants (Castro et al., 2012). In Eucalyptus globulus trees, OCs, mainly OC kappa, induced an increase in net photosynthesis probably leading to an increase in $\mathrm{NAD}(\mathrm{P}) \mathrm{H}$ and in the content of cellulose (González et al., 2013b) as well as activities of $\mathrm{NAD}(\mathrm{P}) \mathrm{H}$-synthesizing enzymes involved in basal metabolism (González, unpublished). Thus, it possible that OC kappa can induce an increase $\mathrm{NAD}(\mathrm{P}) \mathrm{H}, \mathrm{ASC}$, and GSH levels changing the redox status to a more reducing condition that activate TRR/TRX system which may, subsequently, enhance photosynthesis, basal metabolism and growth in Eucalyptus trees.

In order to analyze the influence of OC kappa in the redox status of E. globulus, the levels of NAD(P)H, ASC and GSH and TRR/TRX activities as well as net photosynthesis, activities of enzymes involved in basal metabolism, and growth were determined in control Eucalyptus and in trees treated with OC kappa. In addition, the effects of inhibitors of $\mathrm{NAD}(\mathrm{P}) \mathrm{H}$, ASC, and GSH syntheses corresponding to CHS-828, lycorine and buthionine sulfoximine (BSO), respectively, as well as an inhibitor of TRR, auranofin, were analyzed in control Eucalyptus and in trees treated with OC kappa.

\section{MATERIALS AND METHODS PREPARATION OF OC KAPPA}

OC kappa was prepared from pure commercial kappa2 carrageenan as described in González et al. (2013b).

\section{PLANT CULTURE, TREATMENT WITH OC KAPPA, WITH INHIBITORS AND OC KAPPA, AND MEASUREMENT OF HEIGHT}

E. globulus trees with an initial height of $30 \mathrm{~cm}(n=10$ for each group) were cultivated outdoors during austral summer, from December 2012 to March 2013, in plastic bags containing compost (soil supplemented with leaves of Chilean trees). E. globulus trees were sprayed in the upper and lower part of the leaves with $5 \mathrm{~mL}$ per plant with water/methanol 9:1 v/v (control group $1, n=10$ ), a water/methanol solution of $250 \mu \mathrm{M}$ CHS-828, an 
inhibitor of nicotinamide phosphoribosyl transferase (Olessen et al., 2010) and $\mathrm{NAD}(\mathrm{P}) \mathrm{H}$ synthesis (control group 2, $n=10$ ), a water/methanol solution of $250 \mu \mathrm{M}$ lycorine, an inhibitor of GLDH (Arrigoni et al., 1996), and of ASC synthesis (control group 3, $n=10$ ), a water/methanol solution of $1.5 \mathrm{mM} \mathrm{BSO}$, an inhibitor of $\gamma$-GCS (Griffith and Meister, 1979) and of GSH synthesis (control group 4, $n=10$ ), and with auranofin (Gromer et al., 1998), an inhibitor of TRR activity (control group 5, $n=$ 10), with OC kappa at a concentration of $1 \mathrm{mg} \mathrm{mL}^{-1}$ (treated group 1, $n=10$ ), CHS-828 and OC kappa (treated group 2, $n=10$ ), lycorine and OC kappa (treated group 3, $n=10$ ), BSO and OC kappa (treated group $4, n=10$ ), and auranofine and OC kappa (treated group $5, n=10$ ), and cultivated for 4 months without additional treatment. Trees of control groups 2, 3, 4 and 5 were treated twice with inhibitors, once a week, and then cultivated without additional treatment. Trees of treated groups 2, 3, 4, and 5 were treated twice with inhibitors, once a week, and after 2 weeks they were treated with OC kappa at a concentration of $1 \mathrm{mg}$ $\mathrm{mL}^{-1}$, once a week, four times in total and then cultivated for 4 months without additional treatment. Leaves were obtained from the middle part of control and treated trees and pooled into three groups for further analysis $(n=3)$. The height of trees $(n=10)$ was determined using a measuring tape.

It is important to mention that different concentration CHS-828, lycorine, BSO, and auranofin were sprayed on Eucalyptus leaves in previous experiments to determine the optimal concentration of each inhibitor (data not shown). In addition, it was determined that the optimal concentration of CHS-828 decreased NADPH content, the optimal concentration of lycorine inhibited galatonolactone dehydrogenase (GLDH) activity, the optimal concentration of BSO inhibited $\gamma$-GCS activity, and the optimal concentration of auranofin inhibited TRR activity, up to 4 months of culturing (see Supplementary Fig. 1).

\section{DETERMINATION OF NAD(P)H LEVELS}

The extraction of reduced pyridine nucleotides was performed as described in Brugidou et al. (1991). Reduced pyridine nucleotides (NADH and NADPH) were extracted from leaves [ $1 \mathrm{~g}$ of fresh tissue (FT)] of control and treated Eucalyptus trees $(n=3$ for each group). Leaves were frozen in liquid nitrogen and pulverized in a mortar with a pestle. Five $\mathrm{mL}$ of $0.5 \mathrm{M} \mathrm{HClO}_{4}$ in $10 \%$ methanol were added and homogenization was pursued until thawing. The homogenate was filtered through Miracloth (Calbiochem, San Diego, CA). The filtrate was centrifuged at 27,000 $\mathrm{g}$ for $15 \mathrm{~min}$ and the supernatant was recovered. The supernatant was neutralized with $1 \mathrm{M} \mathrm{KOH}$ to reach $\mathrm{pH}=5.0$ and dried in a vacuum evaporator Savant model SpeedVac. The pellet was solubilized in $0.5 \mathrm{~mL}$ of $10 \mathrm{mM}$ buffer phosphate $\mathrm{pH}=6.5$. Oxidized pyridine nucleotides (NAD and NADP) were extracted from leaves ( $1 \mathrm{~g}$ of FT) as described above using $5 \mathrm{~mL}$ of $0.5 \mathrm{M} \mathrm{NaOH}$ in $10 \%$ methanol and the extract neutralized with $1 \mathrm{M} \mathrm{HCl}$ to reach $\mathrm{pH}=8.0$.

Pyridine nucleotides were analyzed by High Performance Liquid Chromatography (HPLC) using an Agilent 1260 Infinity system and data was compiled using OpenLAB software. Pyridine nucleotides $(20 \mu \mathrm{L})$ were separated on a reversed-phase C-18 column ( $5 \mu \mathrm{m}$ particle size, $4.6 \mathrm{~mm}$ inner diameter, $15 \mathrm{~cm}$ length) at $22^{\circ} \mathrm{C}$, eluted using solvent $\mathrm{A}(50 \mathrm{mM}$ ammonium acetate $\mathrm{pH} 6.9)$ and solvent B (100\% acetonitrile) with linear step gradients of $25 \mathrm{~min}$ from 0 to $5 \%$ of solvent B, 7 min from 5 to $95 \%$ of solvent B, 3 min from 95 to $100 \%$ of solvent B and 10 min of $0 \%$ solvent B

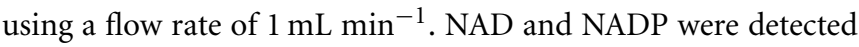
by absorbance at $260 \mathrm{~nm}$ using a diode array detector and NADH and NADPH using an excitation wavelength of $340 \mathrm{~nm}$ and emission wavelength of $480 \mathrm{~nm}$, using a fluorescence detector. Pure NADPH, NADH, NAD, and NADP (Sigma St. Louis, USA) were dissolved in filtered water and used as standards. Retention times of $\mathrm{NADPH}, \mathrm{NADH}, \mathrm{NAD}$, and NADP were 6.3, 10.7, 31.1, and $32.6 \mathrm{~min}$, respectively.

\section{DETERMINATION OF ASC, DHA, GSH, AND GSSG LEVELS}

The levels of ASC, DHA, GSH, and GSSG were determined as described by Ratkevicius et al. (2003). For detection of ASC/DHA and GSH/GSSG, $1 \mathrm{~g}$ of leaves (FT) was used in each case.

\section{PREPARATION OF PROTEIN EXTRACTS}

Eucalyptus leaves ( $5 \mathrm{~g}$ of FT) extracts were prepared as described in Castro et al. (2012) but proteins in extracts were precipitated with ammonium sulfate at $0.6 \mathrm{~g} \mathrm{~mL}^{-1}$ of extract.

\section{DETERMINATION OF GLDH AND $\gamma$-GCS ACTIVITIES}

GLDH and $\gamma$-GCS activity was determined as described in Mellado et al. (2012).

\section{DETERMINATION OF TRR AND TRX ACTIVITIES}

TRR activity was detected as described in Arnér and Holmgren (2001) using $1 \mathrm{~mL}$ of reaction mixture containing $100 \mathrm{mM}$ HEPES buffer $\mathrm{pH}=7.6,0.5 \mathrm{mM}$ dithionitrobenzoic acid (DTNB), $0.3 \mathrm{mM}$ NADPH and $20 \mu \mathrm{g}$ of protein extract. The increase in absorbance due to thionitrobenzoate (TNB) synthesis was measured at $412 \mathrm{~nm}$ for $5 \mathrm{~min}$. TRR activity was calculated using the extinction coefficient of TNB $\left(\varepsilon=14.45 \mathrm{mM}^{-1} \mathrm{~cm}^{-1}\right)$.

TRX activity was detected as described in Arnér and Holmgren (2001) using $1 \mathrm{~mL}$ of reaction mixture containing $100 \mathrm{mM}$ HEPES $\mathrm{pH}=7.6,0.13 \mathrm{mM}$ human insulin, $0.3 \mathrm{mM}$ DTT and $20 \mu \mathrm{g}$ of protein extract. The increase in turbidity was measured at $650 \mathrm{~nm}$ for $3 \mathrm{~min}$. TRX activity was calculated using turbidity coefficient of the large chain of human insulin at $650 \mathrm{~nm}$ $\left(\varepsilon=34 \mathrm{mM}^{-1} \mathrm{~cm}^{-1}\right)$. Regarding TRX activity, it is important to point out that extracts precipitated with ammonium sulfate did contain small molecules such as NADPH that activate TRR, and the reduction of TRR was obtained using DTT.

\section{DETERMINATION OF BASAL METABOLISM ENZYME ACTIVITIES}

Rubisco activity was detected as described in Lilley and Walker (1974) using $1 \mathrm{~mL}$ reaction mixture containing $100 \mathrm{mM}$ Tris$\mathrm{HCl}$ (pH 8.0), $1 \mathrm{mM}$ ribulose 1,5-biphosphate, $10 \mathrm{mM} \mathrm{KHCO}_{3}$, $20 \mathrm{mM} \mathrm{MgCl}$, $5 \mathrm{mM}$ creatine phosphate, $3 \mathrm{mM} \mathrm{ATP,} 10 \mathrm{U}$ phosphoglycerate kinase, $10 \mathrm{U}$ glyceraldehyde 3-phosphate dehydrogenase, $10 \mathrm{U}$ creatine kinase, $0.15 \mathrm{mM} \mathrm{NADH}$ and $10 \mu \mathrm{g}$ of protein extract. The decrease in absorbance at $340 \mathrm{~nm}$ due to consumption of NADH was detected for 3 min. Rubisco activity was calculated using the extinction coefficient of $\mathrm{NADH}(\varepsilon=$ $\left.6.2 \mathrm{mM}^{-1} \mathrm{~cm}^{-1}\right)$.

GlnS activity was determined as described in Barbosa et al. (2010) using $1 \mathrm{~mL}$ of reaction mixture containing $200 \mathrm{mM}$ 
HEPES buffer (pH 7.0), $50 \mathrm{mM}$ L-glutamate, $5 \mathrm{mM}$ hydroxylamine, $50 \mathrm{mM}$ magnesium chloride, $20 \mathrm{mM}$ ATP and $100 \mu \mathrm{g}$ of protein extract. The reaction was incubated at $37^{\circ} \mathrm{C}$ for $1 \mathrm{~h}$ and stopped by addition of $1 \mathrm{~mL}$ mixture containing $0.7 \mathrm{M}$ ferric chloride, $20 \%(\mathrm{w} / \mathrm{v})$ trichloroacetic acid and $0.3 \mathrm{M} \mathrm{HCl}$. The mixture was centrifuged at 7,400 $\mathrm{g}$ for $5 \mathrm{~min}$ and the supernatant was recovered. The absorbance of the supernatant was detected at $540 \mathrm{~nm}$. GlnS activity was calculated using the extinction coefficient of $\gamma$-glutamyl-hydroxamate $\left(\varepsilon=0.85 \mathrm{mM}^{-1} \mathrm{~cm}^{-1}\right)$.

APR activity was determined as described by Brychkova et al. (2012) using $1 \mathrm{~mL}$ in $0.1 \mathrm{~mL}$ of reaction mixture containing $70 \mathrm{mM}$ Tris-acetate $\mathrm{pH}=8.0,350 \mathrm{mM}$ sodium sulfate, $300 \mathrm{mM}$ adenosine 5'phosphosulfate (APS), $4.8 \mathrm{mM}$ reduced glutathione (GSH) and $20 \mu \mathrm{g}$ of protein extract. The reaction mixture was incubated for $30 \mathrm{~min}$ at $35^{\circ} \mathrm{C}$ and an aliquot of $50 \mu \mathrm{L}$ was added to $450 \mu \mathrm{L}$ of the coloring mixture containing $340 \mathrm{mM}$ fuchsin, $230 \mathrm{mM}$ sulphuric acid, and $0.1 \mathrm{mM}$ formaldehyde. APR activity was measured by the increase in absorbance at $570 \mathrm{~nm}$ due to the formation of a colored complex, and calculated using the extinction coefficient of the colored complex $\left(\varepsilon=40 \mathrm{mM}^{-1} \mathrm{~cm}^{-1}\right)$.

O-ASTL activity was determined as described in Lunn et al. (1990) using $1 \mathrm{~mL}$ of reaction mixture containing $50 \mathrm{mM}$ phosphate buffer $\mathrm{pH}=7.5,10 \mathrm{mM} \mathrm{O}$-acetylserine, $2 \mathrm{mM} \mathrm{Na} \mathrm{Na}_{2} \mathrm{~S}$, $30 \mathrm{mM}$ DTT, and $30 \mu \mathrm{g}$ protein extract. The reaction was incubated at $37^{\circ} \mathrm{C}$ for $1 \mathrm{~h}$ and the reaction was stopped by addition of $0.5 \mathrm{~mL}$ of $20 \%(\mathrm{w} / \mathrm{v})$ trichloroacetic acid. Cysteine was detected by adding $100 \mu \mathrm{L}$ of acetic acid and $200 \mu \mathrm{L}$ of ninhydrin reagent [ $250 \mathrm{mg}$ of ninhydrin dissolved in $10 \mathrm{~mL}$ of concentrated acetic acid: concentrated $\mathrm{HCl}$ 60:40 (v/v)]. The mixture was placed in boiling water for $10 \mathrm{~min}$, rapidly cooled in ice and $550 \mu \mathrm{L}$ of 95\% (v/v) ethanol were added. The absorbance of the mixture was determined at $560 \mathrm{~nm}$ and O-ASTL activity was determined using the extinction coefficient the spirane formed by cysteine and ninhydrin $\left(\varepsilon=25 \mathrm{mM}^{-1} \mathrm{~cm}^{-1}\right)$.

Pyruvate dehydrogenase $(\mathrm{PDH})$, isocitrate dehydrogenase parethesis (IDH), 2-oxoglutarate dehydrogenase (OGDH) activities belonging to the Krebs cycle, inosinemonophosphate dehydrogenase (IMPDH), and dihydroorotate dehydrogenase (DHODH) activities involved in purine/pyrimidine synthesis, and glucose 6-P dehydrogenase (G6PDH) activity were determined as described in Castro et al. (2012).

\section{STATISTICAL ANALYSIS}

Significant differences were determined by Two-Way analysis of variance (ANOVA) followed by Tukey's multiple comparison tests $(T)$. To analyze height, mean values were obtained from ten trees, whereas for the rest of the parameters three independent samples of leaves were used. Differences between mean values were considered to be significant at a probability below $5 \%(P<0.05)$, as described by Zar (1999).

\section{RESULTS}

OC KAPPA-INDUCED INCREASE IN NADPH SYNTHESIS REQUIRES THE INCREASE IN ASC SYNTHESIS AND TRR/TRX ACTIVITIES, BUT NOT GSH SYNTHESIS

At 4 months after treatment, NADPH content in control Eucalyptus was c. (aproximately) $10.8 \mu \mathrm{g} \mathrm{g}^{-1}$ of FT, and in trees treated with OC kappa it was c. $15.3 \mu \mathrm{g} \mathrm{g}^{-1}$ of FT, corresponding to a c. $42 \%$ increase in OC kappa-treated trees in relation to controls (Figure 1A). The increase in NADPH in OC kappa-treated trees was observed to decrease under CHS-828, lycorine, and auranofin, but that was not observed with BSO at 4 months experiments (Figure 1B). In contrast, NADH content did not change significantly under OC kappa treatment (Figure 1C). NADH decreased with CHS-828 and auranofin below levels recorded in controls, decreased in relation to OC kappa-treated by lycorine, but did not change with BSO (Figure 1D).

\section{OC-KAPPA-INDUCED INCREASE IN ASC SYNTHESIS REQUIRES THE INCREASE IN NADPH SYNTHESIS AND TRR/TRX ACTIVITIES, BUT NOT GSH SYNTHESIS}

After 4 months treatment, ascorbate (ASC) content in control Eucalyptus was c. $1.1 \mathrm{mg} \mathrm{g}^{-1} \mathrm{FT}$, whereas in trees treated with OC kappa it was c. $1.9 \mathrm{mg} \mathrm{g}^{-1} \mathrm{FT}$, corresponding to a c. $73 \%$ increase in OC kappa-treated trees in relation to controls (Figure 2A). Dehydroascorbate (DHA) content in control trees was c. $0.1 \mathrm{mg}$ $\mathrm{g}^{-1}$ FT and in trees treated with OC kappa it was c. $0.3 \mathrm{mg} \mathrm{g}^{-1}$ FT, which corresponds to about 3 -fold increase (Figure 2B). The activity of GLDH, the last and regulatory enzyme of ASC synthesis, was $32 \mu$ moles $\min ^{-1} \mathrm{mg}^{-1}$ protein in controls, while in OC kappa-treated trees it was $53 \mu$ moles $\mathrm{min}^{-1} \mathrm{mg}^{-1}$ protein, corresponding to a c. $66 \%$ increase (Figure 2C). ASC synthesis decreased after treatment with CHS-828, lycorine and auranofin to c. 18,27 , and $36 \%$, respectively, but did not change with BSO (Figure 2D).

\section{OC-KAPPA-INDUCED INCREASE IN GSH SYNTHESIS REQUIRES THE INCREASE IN NADPH SYNTHESIS AND TRR/TRX ACTIVITIES, BUT NOT ASC SYNTHESIS}

At 4 months after treatment, glutathione (GSH) content in control Eucalyptus was c. $0.3 \mathrm{mg} \mathrm{g}^{-1} \mathrm{FT}$ and in OC kappa-treated trees was c. $0.4 \mathrm{mg} \mathrm{g}^{-1} \mathrm{FT}$, corresponding to a c. $33 \%$ increase (Figure 3A). Oxidized glutathione (GSSG) content in control trees was $0.1 \mathrm{mg} \mathrm{g}^{-1} \mathrm{FT}$ and in trees treated with OC kappa it was $0.2 \mathrm{mg} \mathrm{g}^{-1} \mathrm{FT}$, which is 2 -fold increase in relation to controls (Figure 3B). The activity of $\gamma$-GCS, the first and regulatory enzyme of GSH synthesis, was c. $72 \mu$ moles $\mathrm{min}^{-1} \mathrm{mg}^{-1}$ protein in control trees and c. $112 \mu$ moles $\mathrm{min}^{-1} \mathrm{mg}^{-1}$ protein OC kappa-treated trees, a c. 57\% (Figure 3C). In relation to OC kappa treatment, there was a decrease in GSH levels in c. $33 \%$ under CHS-828, BSO, and auranofin, but not with lycorine (Figure 3D).

\section{OC-KAPPA-INDUCED INCREASE IN TRR/TRX REQUIRES THE INCREASE IN NADPH SYNTHESIS, BUT NOT ASC AND GSH SYNTHESES}

TRR activity in control Eucalyptus trees was c. $60 \mu$ moles $\mathrm{min}^{-1}$ $\mathrm{mg}^{-1}$ protein and in trees treated with OC kappa it was $93 \mu$ moles $\mathrm{min}^{-1} \mathrm{mg}^{-1}$ protein, at 4 months after treatment, corresponding to a c. $55 \%$ increase (Figure $4 \mathrm{~A}$ ). At 4 months after treatment, TRR activity decreased in relation to OC kappa treatment under CHS-828 and auranofin to c. 28 and c. $32 \%$, respectively, but not with lycorine or BSO (Figure 4B). In addition, TRX activity in control trees was c. $11 \mu$ moles $\mathrm{min}^{-1} \mathrm{mg}^{-1}$ protein and in OC kappa-treated trees was c. $17 \mu$ moles $\mathrm{min}^{-1} \mathrm{mg}^{-1}$ protein, corresponding to a c. 55\% increase (Figure 4C). TRX activity decreased 


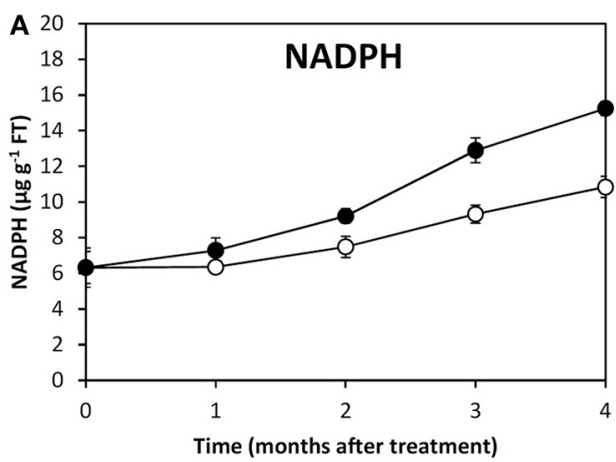

C

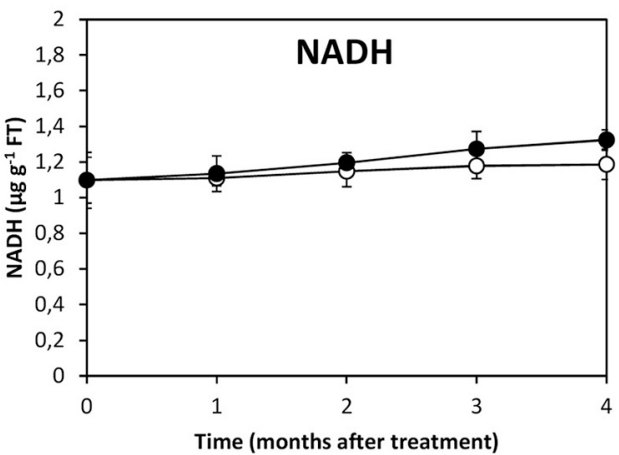

FIGURE 1 | Effect of inhibitors on NADPH synthesis after treatment with OC kappa. Levels of NADPH (A) and NADH (C) in control Eucalyptus trees (empty circles), in trees treated with OC kappa (black circles) and cultivated for 0-4 months without additional treatment. Level of NADPH (B) and NADH (D) in control Eucalyptus trees (control), in trees treated with OC kappa (kappa) and in trees treated with $\mathrm{CHS}-828$ and OC kappa (CHS+K), lycorine

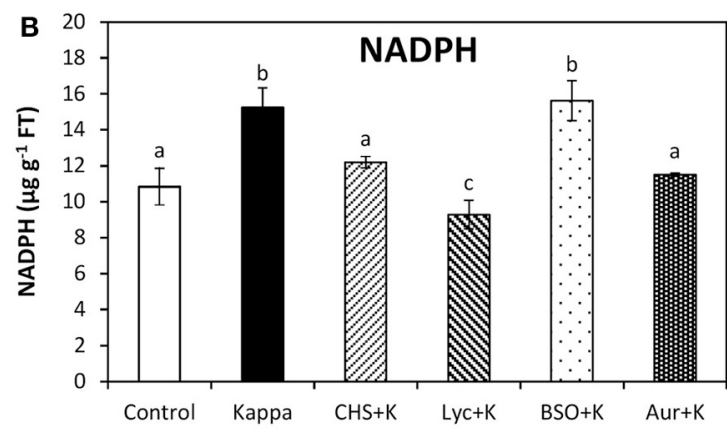

D

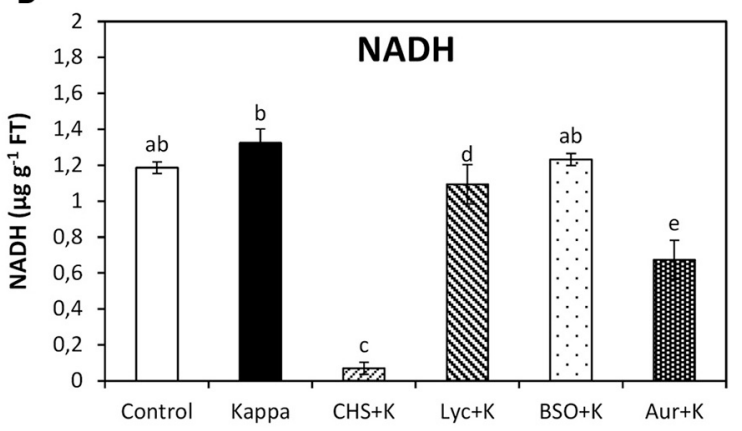

and OC kappa (Lyc+K), buthionine sulfoximine and OC kappa (BSO+K), and auranofin and OC kappa (Aur+K) and cultivated for 4 months without additional treatment. $\mathrm{NAD}(\mathrm{P}) \mathrm{H}$ levels are expressed in micrograms per gram of fresh tissue (FT). Symbols and bars represent mean values of three independent experiments and letters indicate significant differences $(p<0.05)$ under CHS-828 and auranofin in c. 39\% and c. 30\%, respectively, but that was not observed with lycorine or BSO (Figure 4D).

\section{OC KAPPA-INDUCED INCREASE IN HEIGHT AND PHOTOSYNTHESIS REQUIRES THE INCREASE IN NADPH, ASC, GSH SYNTHESES, AND TRR/TRX ACTIVITIES}

At 4 months after treatment, height of control Eucalyptus trees increased in c. $125 \mathrm{~cm}$, whereas OC kappa-treated trees the increase was c. $164 \mathrm{~cm}$, which corresponds to an increase of c. $31 \%$ compared to controls (Figure 5A). The increase in height observed in OC kappa-treated trees for 4 months was inhibited by CHS-828, lycorine, BSO, and auranofin, in c. 22, 14, 17, and $16 \%$, respectively (Figure $5 \mathrm{~B}$ ). Net photosynthesis in control Eucalyptus was c. $48 \mu$ moles $\mathrm{m}^{-2} \mathrm{~s}^{-1}$ and in trees treated with OC kappa for 4 months it was c. $62 \mu$ moles $\mathrm{m}^{-2} \mathrm{~s}^{-1}$, which corresponds to an increase of c. $29 \%$ compared to controls (Figure 5C). The increase in net photosynthesis was inhibited by CHS-828, lycorine, BSO and auranofin in c. 9, 12, 12, and 10\%, respectively (Figure 5D).

\section{OC-KAPPA INCREASE IN BASAL METABOLISM REQUIRES THE INCREASE IN NADPH, ASC AND GSH SYNTHESES, AND TRR/TRX ACTIVITIES}

Rubisco activity, the first and regulatory enzyme of $\mathrm{C}$ assimilation, in control Eucalyptus was c. $81 \mu$ moles $\mathrm{min}^{-1} \mathrm{mg}^{-1}$ protein and in OC kappa-treated trees was c. $244 \mu$ moles $\mathrm{min}^{-1} \mathrm{mg}^{-1}$ protein at 4 months after treatment, corresponding to a 3 -fold increase. Rubisco activity decreased under CHS-828, lycorine, auranofin treatments c. 1.3 , c. 1.3 , and c. 1.5 times, but that was not observed with BSO (Figure 6A). At 4 months after treatment, GlnS activity, the regulatory enzyme of $\mathrm{N}$ assimilation, was c. $7 \mu$ moles $\mathrm{min}^{-1} \mathrm{mg}^{-1}$ protein in control trees and in OC kappa-treated trees was c. $16 \mu$ moles $\mathrm{min}^{-1} \mathrm{mg}^{-1}$ protein, corresponding to a c. 2-fold increase (Figure 6B). GlnS activity decreased under CHS-828 and auranofin c. 1.8 and 1.7 times, respectively, but no significant change was recorded with lycorine or BSO. APR activity, the regulatory enzyme of $S$ assimilation, was $28 \mu$ moles $\mathrm{min}^{-1} \mathrm{mg}^{-1}$ protein in control Eucalyptus and in OC kappa-treated trees was c. 36 , corresponding to a c. $29 \%$ increase. APR activity decreased under CHS-828, auranofin and BSO treatments in c. 7, 14, and 14\%, respectively, although no significant changes were recorded with lycorine (Figure 6C). O-ASTL activity, the last enzyme for S assimilation, in control Eucalyptus trees was c. $9 \mu$ moles $\mathrm{min}^{-1} \mathrm{mg}^{-1}$ protein while in OC kappa-treated trees was c. $12 \mu$ moles $\mathrm{min}^{-1} \mathrm{mg}^{-1}$ protein at 4 months after treatment, corresponding to a c. $33 \%$ increase. O-ASTL activity decreased under CHS-828 and auranofin treatments to c. 22 and $11 \%$, but no change was observed with lycorine or BSO (Figure 6D).

$\mathrm{PDH}$ activity, the first enzyme of the Krebs cycle, was $10 \mu$ moles $\mathrm{min}^{-1} \mathrm{mg}^{-1}$ protein in control Eucalyptus and in OC kappa-treated trees was $13 \mu$ moles $\mathrm{min}^{-1} \mathrm{mg}^{-1}$ protein at 4 

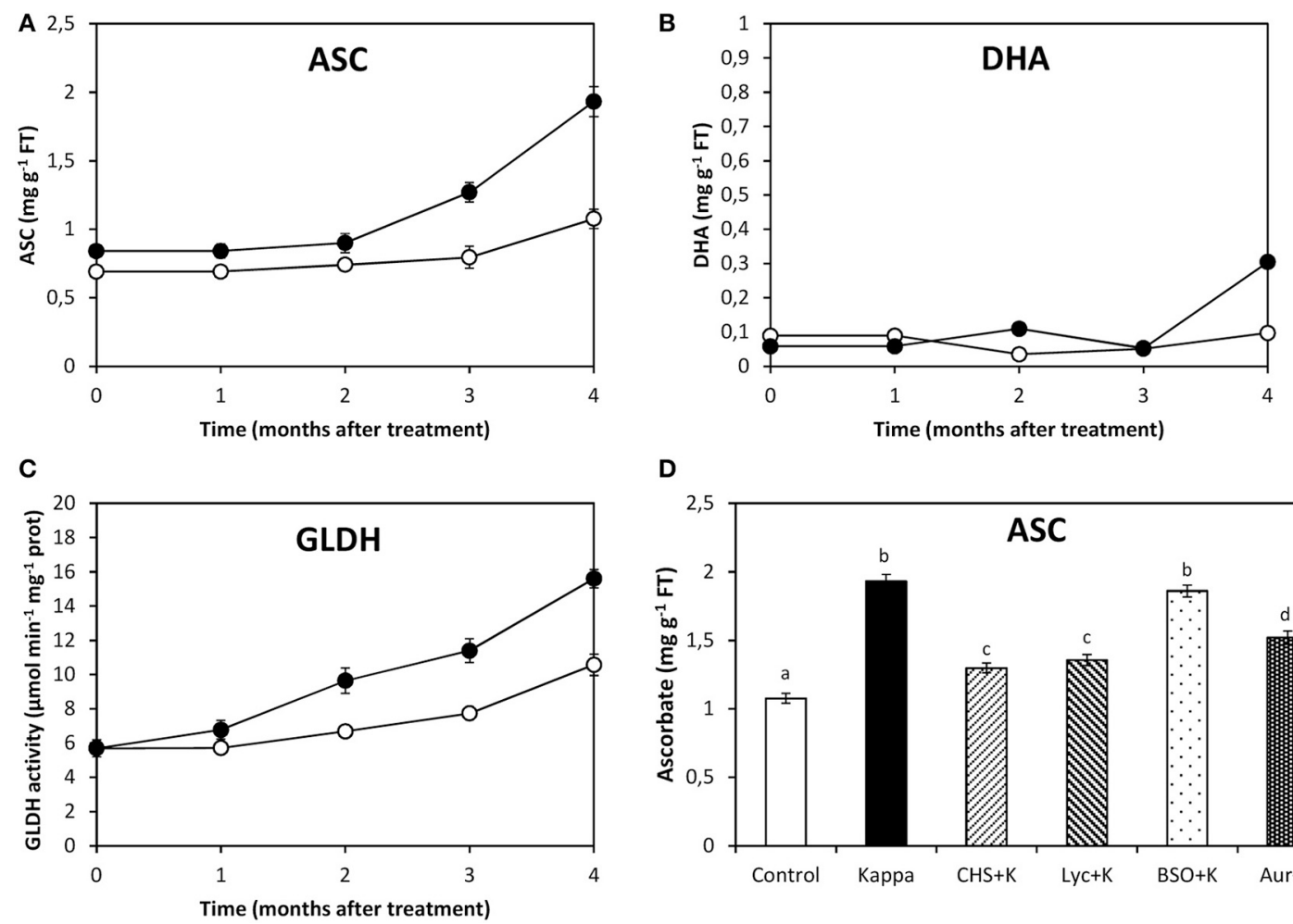

D

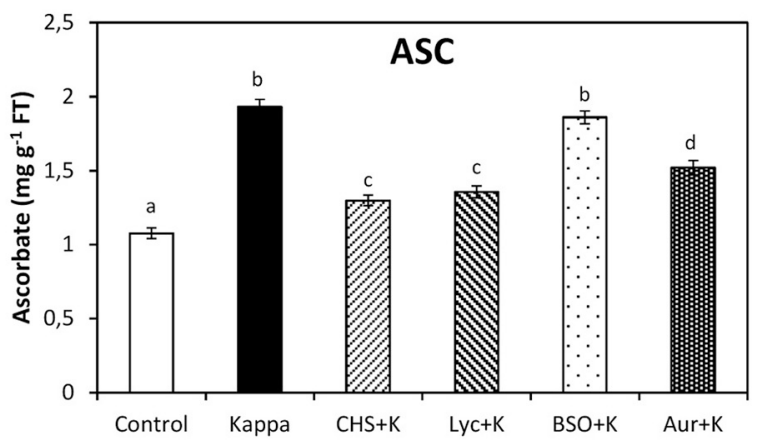

FIGURE 2 | Effect of inhibitors on ASC synthesis after treatment with OC kappa. Level of ascorbate [ASC, (A)] and dehydroascorbate [DHA, (B)], and galatonolactone dehydrogenase [GLDH, (C)] activity in control

Eucalyptus trees (empty circles) and in trees treated with OC kappa (black circles) and cultivated for 0-4 months without additional treatment. Level of ASC (D) in control Eucalyptus trees (control), in trees treated with OC kappa (kappa) and in trees treated with CHS-828 and OC kappa (CHS+K), lycorine and OC kappa (LyC+K), buthionine sulfoximine and OC kappa $(\mathrm{BSO}+\mathrm{K})$ and auranofin and OC kappa (Aur $+\mathrm{K})$ and cultivated for 4 months without additional treatment. ASC and DHA levels are expressed in milligrams per gram of fresh tissue (FT) and the activity of GLDH is expressed in micromoles per minute per milligram of protein. Symbols and bars represent mean values of three independent experiments and letters indicate significant differences $(p<0.05)$. months after treatment, corresponding to a c. 30\% increase. PDH activity decreased under CHS-828 and lycorine and auranofin treatments, although in the latter the decrease was more moderated, but in case of BSO treatment no significant changes were observed with respect to OC kappa-treated trees (Figure 6E). $\mathrm{IDH}$, the fourth enzyme of the Krebs cycle, was c. $23 \mu$ moles $\min ^{-1} \mathrm{mg}^{-1}$ protein in control Eucalyptus and in OC kappatreated trees was c. $33 \mu$ moles $\mathrm{min}^{-1} \mathrm{mg}^{-1}$ protein at 4 months after treatment, corresponding to a c. $43 \%$ increase. IDH activity decreased under CHS-828, lycorine and auranofin in c. 4, 22, and $4 \%$, respectively, but no significant changes were recorded with BSO (Figure 6F). At 4 months after treatment, 2-oxoglutarate dehydrogenase (OGDH) activity, the fifth enzyme of the Krebs cycle, was c. $5 \mu$ moles $\mathrm{min}^{-1} \mathrm{mg}^{-1}$ protein in control Eucalyptus and in OC kappa-treated trees was c. $14 \mu$ moles $\mathrm{min}^{-1} \mathrm{mg}^{-1}$ protein, almost a 3-fold increase. OGDH activity decreased under CHS-828, auranofin, and lycorine treatments, but not with BSO (Figure 6G).

Inosine monophosphate dehydrogenase (IMPDH) activity, involved in purine synthesis, in control Eucalyptus was c. $15 \mu$ moles $\min ^{-1} \mathrm{mg}^{-1}$ protein and in OC kappa-treated was c. $21 \mu$ moles $\min ^{-1} \mathrm{mg}^{-1}$ protein, corresponding to a c. $40 \%$ increase. IMPDH activity markedly decreased under CHS-828, moderately decreased in c. $13 \%$ under auranofin and lycorine, but was not recorded to decrease with BSO (Figure 6H). DHODH activity, involved in pyrimidine synthesis, was c. $6 \mu$ moles $\mathrm{min}^{-1}$ $\mathrm{mg}^{-1}$ protein in control Eucalyptus and c. $9 \mu$ moles $\mathrm{min}^{-1}$ $\mathrm{mg}^{-1}$ protein in OC kappa-treated trees, resultant in a c. $50 \%$ increase. DHODH activity decreased under CHS-828, auranofin and lycorine in c. $17 \%$ in each case, but no significant differences were observed under BSO (Figure 6I). At 4 months after treatment, G6PDH activity, involved in ribose 5-P synthesis, was c. $12 \mu$ moles $\mathrm{min}^{-1} \mathrm{mg}^{-1}$ protein in control Eucalyptus and c. $19 \mu$ moles $\mathrm{min}^{-1} \mathrm{mg}^{-1}$ protein in OC kappa-treated trees, corresponding to a c. $58 \%$ increase. G6PDH activity decreased in CHS-828 and auranofin treatments in c. 17 and 25\%, respectively, but no differences were recorded in lycorine and BSO treatments (Figure 6J).

\section{DISCUSSION}

OC-KAPPA-INDUCED INCREASES IN NADPH, ASC, GSH SYNTHESES, AND TRR/TRX ACTIVITIES ARE CROSS-TALKING EVENTS

In this work, we showed that OC kappa induced a concomitant increase in NADPH, ASC, and GSH syntheses and TRR/TRX activities in Eucalyptus trees and that these increases are cross-talking events. Interestingly, the increase in NADPH 


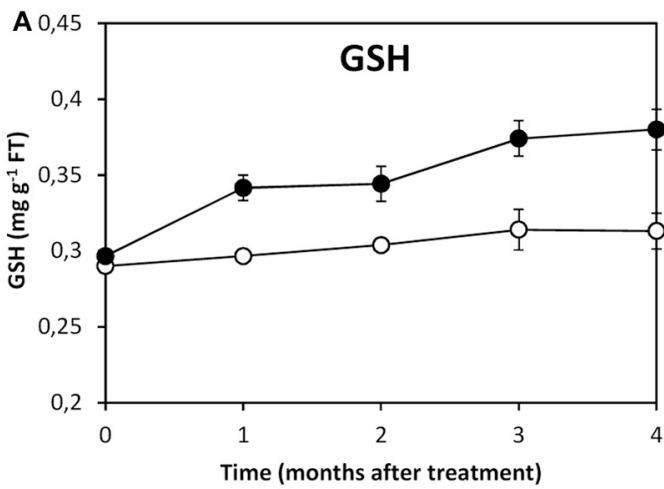

C

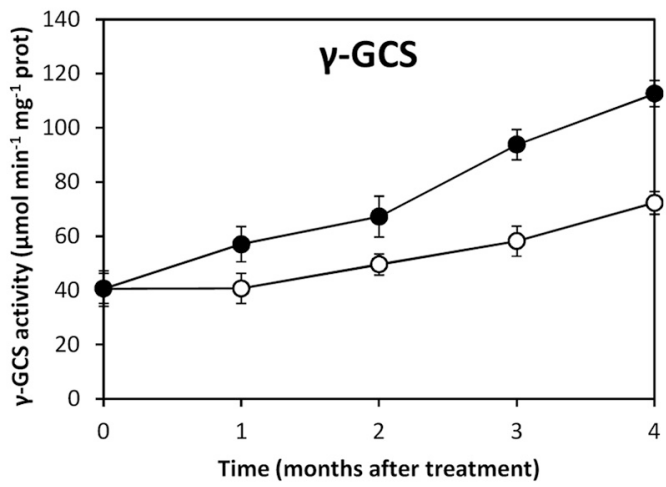

FIGURE 3 | Effect of inhibitors on GSH synthesis after treatment with OC kappa. Level of glutathione [GSH, (A)] and oxidized glutathione [GSSG, (B)] and of $\gamma$-glutamylcysteine synthase [ $\gamma$-GCS, (C)] activity in control Eucalyptus trees (empty circles) and in trees treated with OC kappa (black circles) cultivated for 0-4 months without additional treatment. Level of GSH (D) in control Eucalyptus trees (control), in trees treated with OC kappa (kappa) and in trees treated with $\mathrm{CHS}-828$ and OC kappa $(\mathrm{CHS}+\mathrm{K})$, lycorine and OC

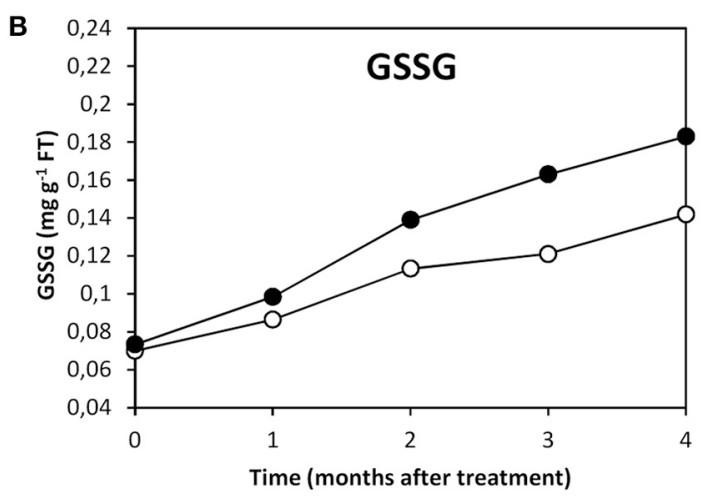

D

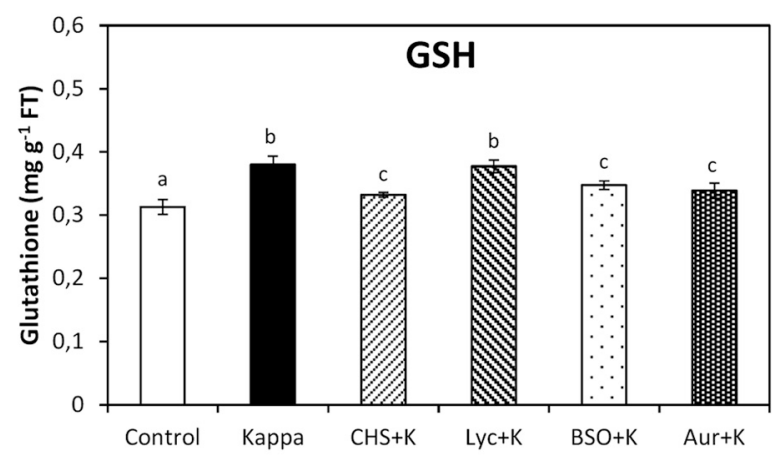

kappa (Lyc+K), buthionine sulfoximine and OC kappa (BSO+K) and auranofin and OC kappa (Aur+K) and cultivated for 4 months without additional treatment. GSH and GSSG levels are expressed in milligrams per gram of fresh tissue (FT) and the activity of $\gamma$-GCS is expressed in micromoles per minute per milligram of protein. Symbols and bars represent mean values of three independent experiments and letters indicate significant differences $(p<0.05)$ was influenced by the increase in ASC and GSH and TRR/TRX activities, but, in contrast, the increase in ASC was influenced only by the increase in NADPH-TRR/TRX, and not by the increase in GSH (see model in Figure 7). In addition, the increase in TRR/TRX activities was only influenced by the increase in $\mathrm{NADPH}$, and not by the increase in ASC and GSH. On the other hand, the increase in ASC, GSH, NADPH, and TRR/TRX activities influenced photosynthesis and growth as well as the activity of several basal metabolism enzymes. However, some basal metabolism enzymes were only influenced by the increase in TRR/TRX activities, and not by the increase in ASC or GSH. Thus, despite that ASC and GSH influenced NADPH synthesis, it appears that NADPH is the heart of the redox status since it directly activates TRR/TRX system which, in turn, activates photosynthesis, basal metabolism and growth in Eucalyptus trees. Surprisingly, only NADPH increased in response to OC kappa and not NADH. Considering that NAD is the precursor of NADP, NAD might have been converted into NADP and then in NADPH. In this sense, it has been observed that NADPH content is higher than NADH in wheat and pea leaves because the NAD kinase, the enzyme that converts NAD in NADP, is mainly located in chloroplast and is light-dependent (Muto et al., 1981). Thus, a similar phenomenon might occur in leaves of Eucalyptus trees treated with OC kappa. In addition, the increase in NADPH synthesis was regulated by TRR/TRX activities suggesting that TRXs participate in the conversion of NAD in NADP. In this regard, it has been observed that NAD kinase is activated by TRXs in Lycopersicon pimpinellifolium (Delumeau et al., 2000) and, thus, a similar process may be occurring in Eucalyptus trees treated with OC kappa. Moreover, the increase in ASC participates in the increase in NADPH suggesting that ASC may protect photosystems and redox-sensitive proteins in chloroplasts (see below), thus, enhancing photosynthesis that produces NADPH. On the other hand, NADPH-TRR/TRX system induced the increase in ASC and GSH syntheses. Until now, there is no evidence indicating that TRXs bind to enzymes involved in ASC or GSH syntheses (Montrichard et al., 2009). However, TRXs bind to phosphoglucomutase (PGM) in the cyanobacteria Synechocystis sp. (Lindhal and Florencio, 2003), an enzyme that converts glucose-1-P into glucose-6-P. Considering that glucose-6-P is a precursor for ASC synthesis (Valpuesta and Botella, 2004), it is possible that the latter is indirectly activated by TRXs through the interaction with PGM. In addition, TRXs activate GluS involved in glutamate synthesis in the green microalga Chlorella sorokiniana 


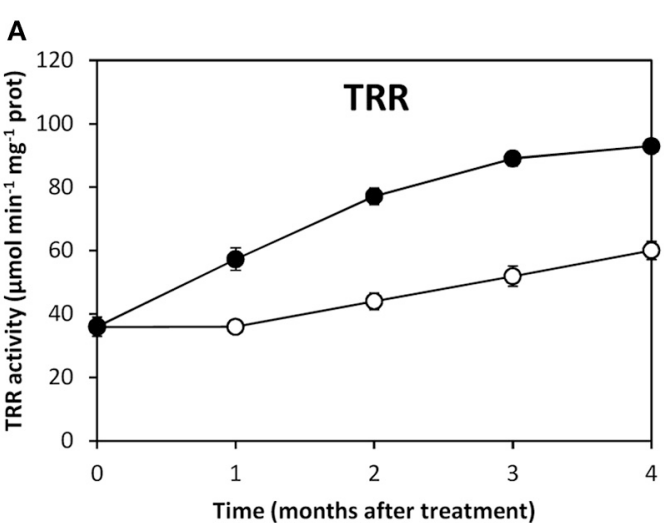

C

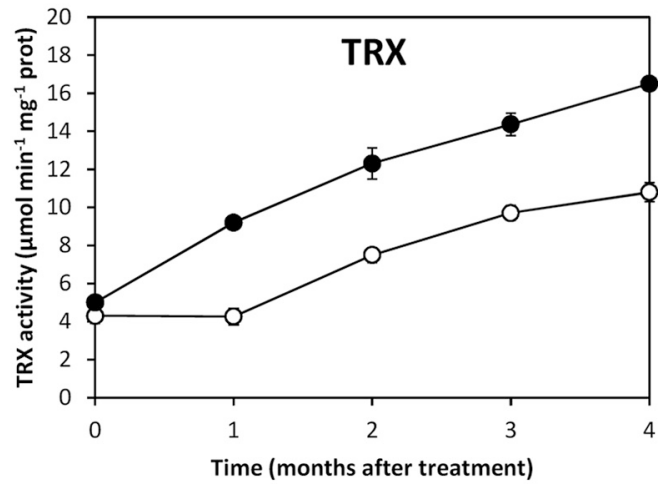

FIGURE 4 | Effect of inhibitors on TRR and TRX activities after treatment with OC kappa. Activities of thioredoxin reductase [TRR, (A)] and thioredoxin [TRX, (C)] in control Eucalyptus trees (empty circles) and in trees treated with OC kappa (black circles) cultivated for 0-4 months without additional treatment. Activities of TRR (B) and TRX (D) in control Eucalyptus trees (control), in trees treated with OC kappa (kappa) and in trees treated

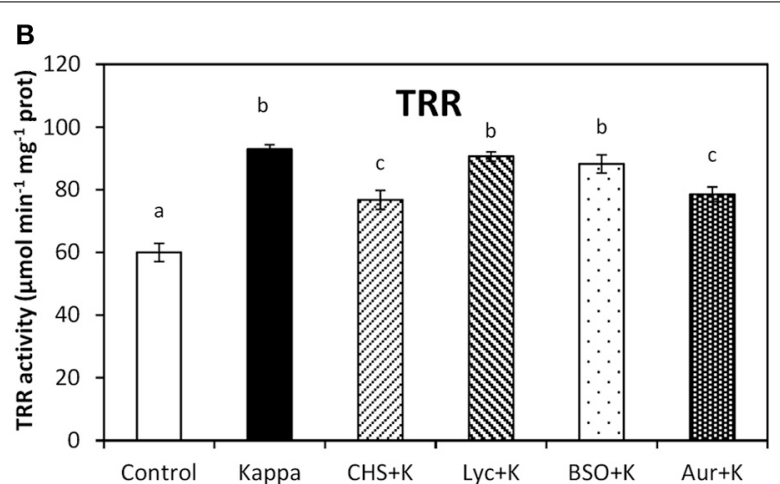

D

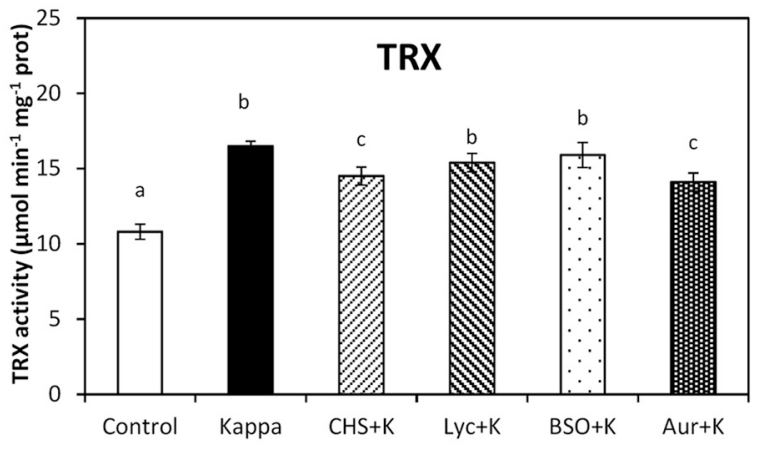

with CHS-828 and OC kappa (CHS+K), lycorine and OC kappa (Lyc+K), buthionine sulfoximine and OC kappa (BSO+K) and auranofin and OC kappa (Aur $+\mathrm{K}$ ) and cultivated for 4 months without additional treatment. TRR and TRX activities are expressed in micromoles per minute per milligram of protein. Symbols and bars represent mean values of three independent experiments and letters indicate significant differences $(p<0.05)$.
(Tischner and Schmidt, 1982), and TRXs bind to a cyclophylin that activates O-ASTL, which is involved in cysteine synthesis in Arabidopsis (Dominguez-Solís et al., 2008). Considering that GSH is constituted by glutamate and cysteine, it is possible that TRXs may interact with enzymes involved in GSH synthesis and, thus, indirectly increasing GSH synthesis.

\section{OC KAPPA-INDUCED INCREASE IN ASC, GSH, AND NADPH SYNTHESES AND TRR/TRX ACTIVITIES, ENHANCE PHOTOSYNTHESIS AND GROWTH}

Our results showed that OC kappa induced an increase in net photosynthesis and growth which were influenced by the increase in ASC, GSH, and NADPH syntheses and TRR/TRX activities in Eucalyptus trees. Regarding the increase in ASC and photosynthesis, it is important to mention that ASC is the substrate of the antioxidant enzyme AP that detoxifies hydrogen peroxide produced by electron transport chains (ETCs) in chloroplasts and mitochondria (Shigeoka et al., 2002). In addition, it has been shown that hydrogen peroxide oxidize sulfhydryl groups of redox-sensitive proteins such as rubisco, RAC, and other Calvin cycle enzymes leading to their inactivation and further degradation (García-Ferris and Moreno, 1993; Moreno et al., 2008).
Moreover, Arabidopsis mutants having a lower ASC content than wild type plants showed degradation of grana stacks in chloroplasts (Olmos et al., 2006). Thus, ASC protects proteins involved in photosynthesis and $\mathrm{C}$ assimilation. Furthermore, ASC also regulates cell division in plants since it allows the transition from G1 to $S$ phase in tobacco cells cultured in vitro and in cells of the quiescent center in onion roots (Liso et al., 1988; De Pinto et al., 1999). Indeed, Arabidopsis mutant vtc-1 having 70\% less ASC in the leaves showed a slower growth rate, smaller leaves and lighter shoots compared to wild-type plants (Veljovic-Jovanovic et al., 2001). Thus, the increase in ASC synthesis observed in Eucalyptus trees treated with OC kappa may provide protection of redox-sensitive enzymes and photosystems leading to an increase in photosynthesis which, added to the ASC-dependent stimulation of cell division may determine, at least in part, the increase in growth.

Regarding the increase in GSH and photosynthesis, it has been recently recorded that cucumber plants treated with a brassinosteroid showed an increase in GSH/GSSG ratios, in activities of rubisco and other Calvin-Benson cycle enzyme activities as well as in the content of RAC (Jiang et al., 2012). In addition, it has been observed that GSH is required for transition from G1 to $S$ phase in 


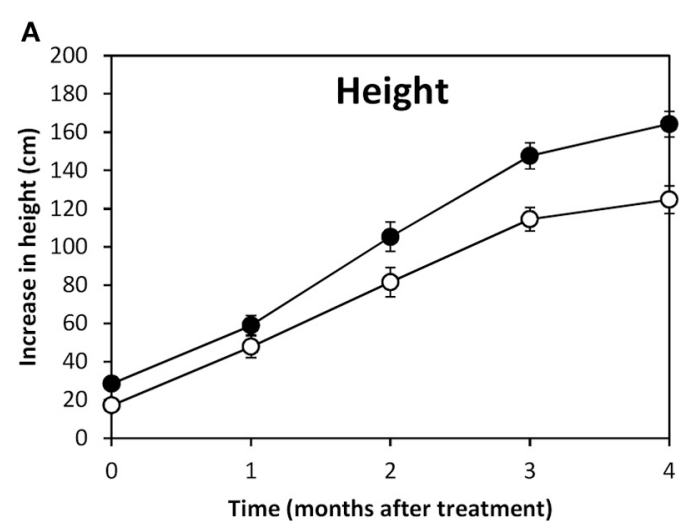

C

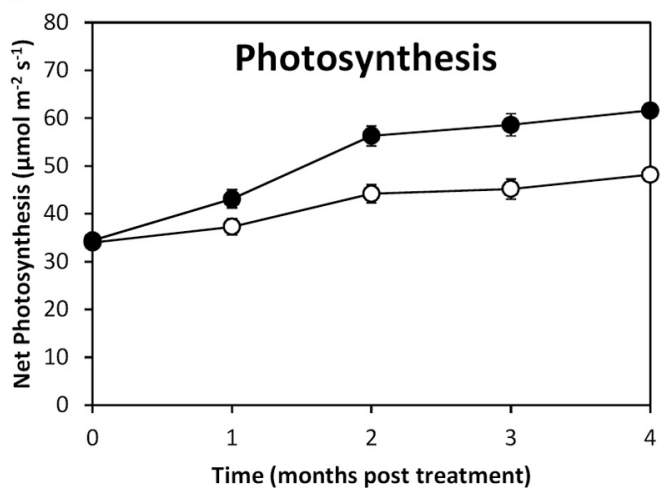

FIGURE 5 | Effect of inhibitors on height and photosynthesis after treatment with OC kappa. Increase in height (A) and net photosynthesis (C) in control Eucalyptus trees (empty circles), in trees treated with OC kappa (black circles) and cultivated for 0-4 months without additional treatment. Increase in height (B) and net photosynthesis (D) in control Eucalyptus trees (control), in trees treated with OC kappa (kappa) and in trees treated with CHS-828 and OC

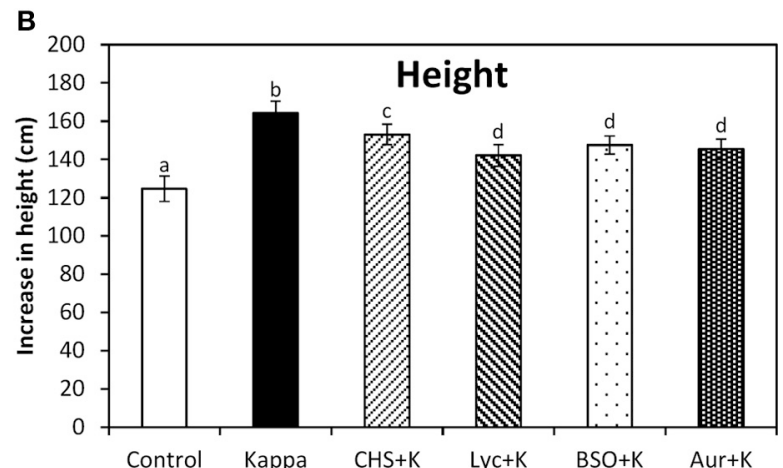

D

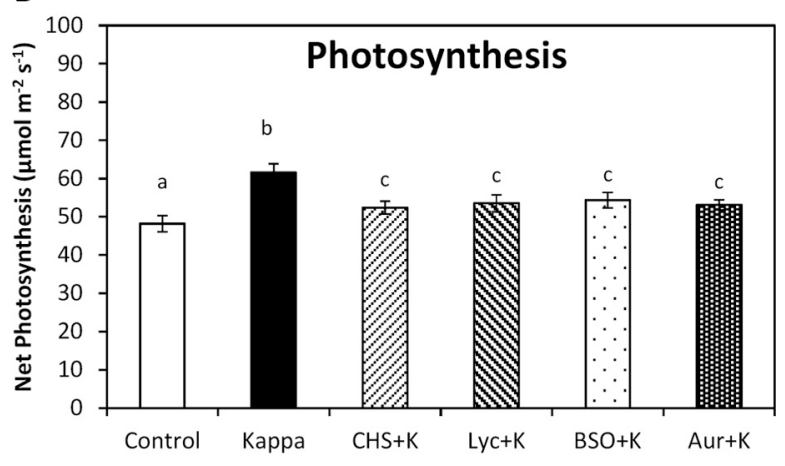

kappa (CHS+K), lycorine and OC kappa (Lyc+K), buthionine sulfoximine and $\mathrm{OC}$ kappa $(\mathrm{BSO}+\mathrm{K})$ and auranofin and $\mathrm{OC}$ kappa (Aur+K) and cultivated for 4 months without additional treatment. The increase in height is expressed in centimeters and net photosynthesis in micromoles per meter square per second. Symbols and bars represent mean values of three independent experiments and letters indicate significant differences $(p<0.05)$ tobacco cells cultured in vitro and cell division in the apical meristems of Arabidopsis roots (Vernoux et al., 2000). Furthermore, Arabidopsis mutants having a mutation in the gene encoding $\gamma$-GCS and in a NADPH-dependent TRR showed a smaller size of shoots and roots (Bashandi et al., 2010). Thus, the increase in GSH levels observed in Eucalyptus trees treated with OC kappa may participate in the increase of photosynthesis, which added to the GSH-dependent increase in cell division may determine, at least in part, the increase in growth.

Regarding the increase in NADPH-TRR/TRX system and photosynthesis, it has been shown that TRXs interact with protein D1 protecting PSII from oxidative damage in Arabidopsis (Ströher and Dietz, 2008) and with subunits of chloroplast ATPase in Chlamydomonas reinhardtii (Lemaire et al., 2004). Moreover, Wang et al. (2013) observed that TRXs-silenced Arabidopsis evidenced elevated content of reactive oxygen species and high levels of oxidized subunit CP47 in PSII, explaining the pale green aspect of leaves. In addition, TRX $f$ and TRX $m$ increased ATPase activity of the subunit CHLI of magnesium chelatase leading to an increase in chlorophyll content and photosynthesis in pea plants (Luo et al., 2012). Therefore, the increase in NADPH synthesis and TRR/TRX activities observed in Eucalyptus trees treated with OC kappa may increase chlorophyll synthesis and protection of photosystems leading to an increase in photosynthesis which may determine, at least in part, the increase in growth.

\section{OC-KAPPA-INDUCED INCREASE IN NADPH, ASC, GSH SYNTHESES, AND TRR/TRX ACTIVITIES ENHANCE BASAL METABOLISM}

In addition, it was observed that the increase in ASC, GSH, and NADPH syntheses and TRR/TRX activities participate in the increase in nutrient assimilation since the increase in ASC, $\mathrm{NADPH}$, and TRR/TRX activities enhanced rubisco activity, the increase in GSH synthesis and TRR/TRX activities enhanced APR activity, and the increase in NADPH synthesis and TRR/TRX activities enhanced GlnS and O-ASTL activities (see model in Figure 7). Regarding rubisco activity and ASC, it is well known that ASC protects rubisco and RAC from oxidation of in their sulfhydryl groups, avoiding their inactivation and degradation (García-Ferris and Moreno, 1993; Moreno et al., 2008). In contrast, rubisco activity was not regulated by GSH content in OC kappa-treated Eucalyptus trees, in disagreement with Jiang et al. (2012), which observed that an increase in GSH/GSSG 

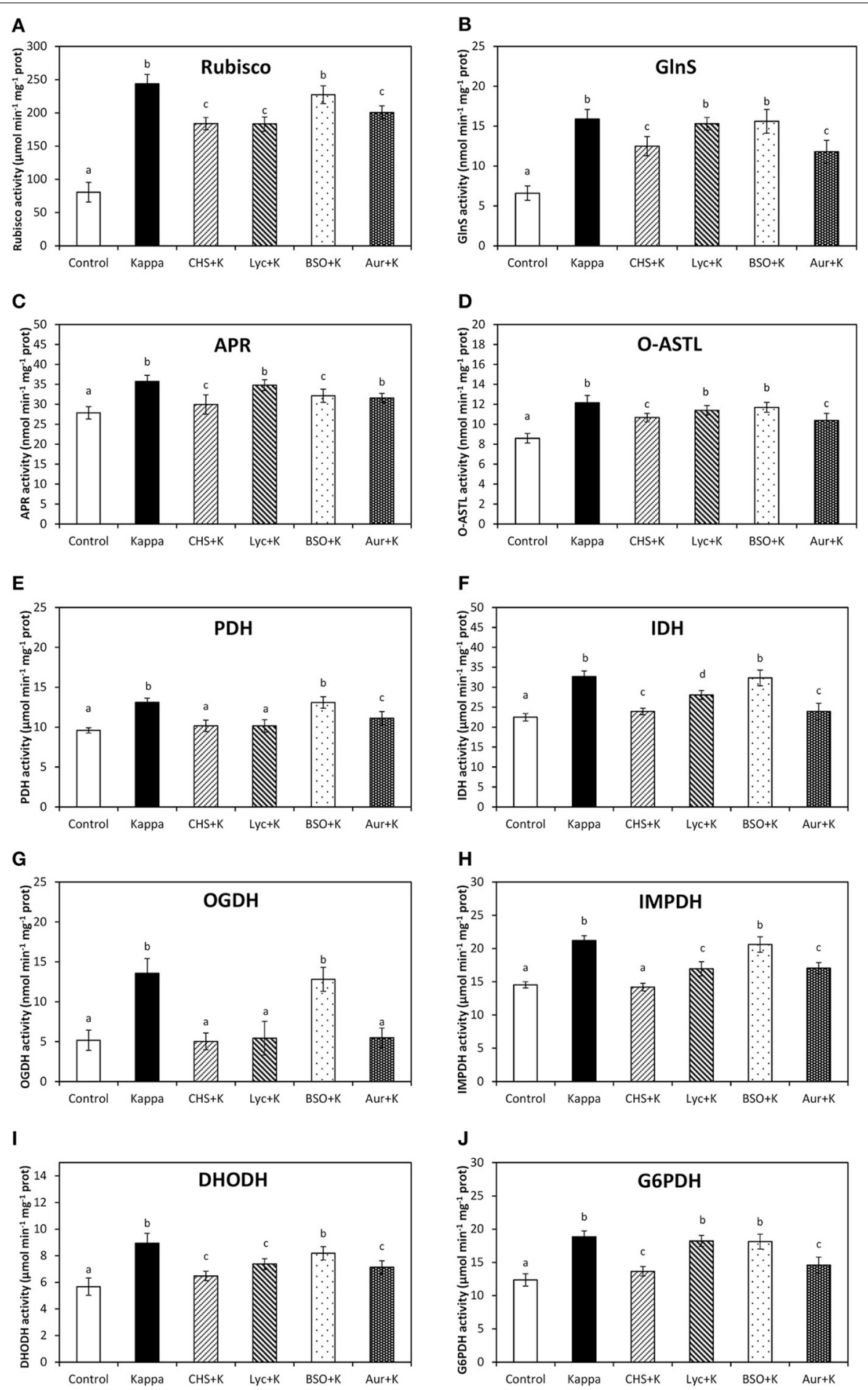

FIGURE 6 | Effect of inhibitors on basal metabolism enzymes activities after treatment with OC kappa. Activities of rubisco (A), glutamine synthetase [GInS, (B)], adenosine $5^{\prime}$ phosphosulfate reductase [APR, (C)], O-acetylserinethiol-lyase [O-ASTL, (D)], pyruvate dehydrogenase $[\mathrm{PDH},(\mathbf{E})]$, isocitrate dehydrogenase [IDH, (F)], 2-oxoglutarate dehydrogenase [OGDH, (G)], inosine monophosphate dehydrogenase [IMPDH, (H)], dihydroorotate dehydrogenase [DHODH, (I)], and glucose 6-phospahte dehydrogenase [G6PDH, (J)] in control Eucalyptus trees (control), in trees treated with OC kappa (kappa) and

$\mathbf{J}$

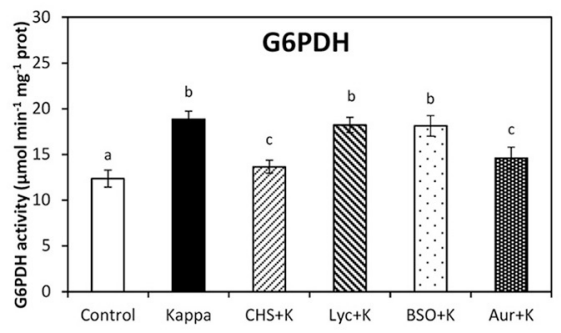

in trees treated with $\mathrm{CHS}-828$ and OC kappa $(\mathrm{CHS}+\mathrm{K})$, lycorine and $\mathrm{OC}$ kappa (Lyc+K), buthionine sulfoximine and OC kappa (BSO+K) and auranofin and OC kappa (Aur+K) and cultivated for 4 months without additional treatment. Activities of rubisco, O-ASTL PDH, IDH, OGDH, IMPDH, DHODH, and G6PDH are expressed in micromoles per minute per milligram of protein and activities of GInS and APR are expressed in nanomoles per minute per milligram of protein. Bars represent mean values of three independent experiments and letters indicate significant differences $(p<0.05)$. 


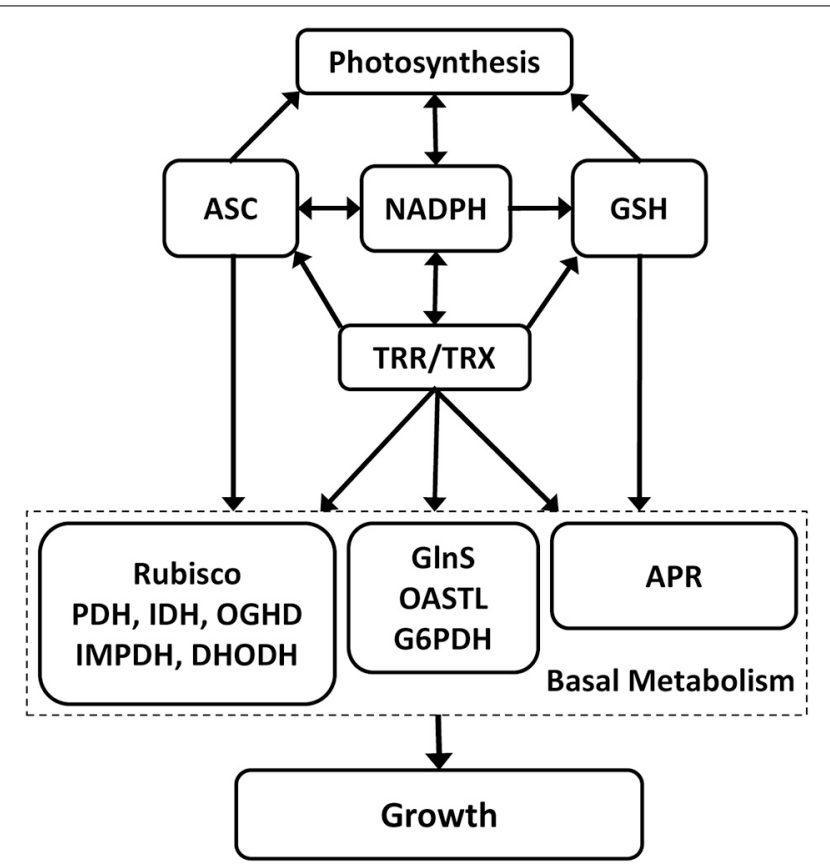

FIGURE 7 | Model of the interdependence in the increases of NADPH, ascorbate (ASC), glutathione (GSH) syntheses, and TRR (thioredoxin reductase)/TRX (thioredoxin) activities and their interaction with photosynthesis, basal metabolism, and growth. ratios provides protection of rubisco, Calvin cycle enzymes, and RAC from oxidation and degradation. In this sense, it is important to mention that GSH/GSSG ratios did not increase in Eucalyptus trees treated with OC kappa (see Supplementary Fig. 2), which would provide explanation for this apparent inconsistency. Regarding the increase in rubisco activity and TRXs, it has been shown that TRXs induce an increase RAC activity which, in turn, activates rubisco in Arabidopsis (Zhang and Portis, 1999). Regarding the increase in GSH and APR activity, it is not surprising that GSH enhanced APR activity since GSH is a substrate of this enzyme (Vauclaire et al., 2002). Regarding the increase in GlnS and O-ASTL actitvities and NADPH-TRR/TRX system, it has been observed that GlnS is activated by TRXs in the green microalga Chlorella sorokiniana (Tischner and Schmidt, 1982), and that O-ASTL activated by a cyclophylin in Arabidopsis that is, in turn, is activated by a TRX (Dominguez-Solís et al., 2008). Thus, the increase in ASC, GSH and NADPH syntheses and TRR/TRX activities enhanced $\mathrm{C}, \mathrm{N}$ and $\mathrm{S}$ assimilation in Eucalyptus trees treated with $\mathrm{OC}$ kappa, indicating that a reducing redox status favors nutrient assimilation.

In addition, the increase in NADPH and ASC syntheses and TRR/TRX activities enhanced Krebs cycle enzyme activities PDH, IDH, and OGDH. The regulation of Krebs cycle enzymes by ASC suggest that these enzymes are redox-sensitive, as it has been previously shown for $\mathrm{PDH}$ and $\mathrm{OGDH}$ in Arabidopsis (Sweetlove et al., 2002). Moreover, purine and pyrimidine synthesis enzymes IMPDH and DHODH, respectively, were also influenced by ASC and NADPH-TRR/TRX in OC kappa-treated trees. In this sense, there is evidence suggesting that TRXs participate in regulating DHODH since it has been observed that TRXs bind to DHODH in barley (Hägglund et al., 2008). No information is now available regarding the activation of IMPDH by TRXs. In contrast, G6PDH, which produces ribose 5-P, was only regulated by NADPH-TRR/TRX system, which is in agreement with the findings by Née et al. (2009) that observed the activation of G6PDH by TRXs in Arabidopsis. Thus, the increase in ASC, GSH NADPH syntheses, and TRR/TRX activities enhanced basal metabolism in Eucalyptus trees explaining, at least in part, the increase in growth induced by OC kappa (see model in Figure 7).

Although different investigations have demonstrated that OCs stimulate photosynthesis, basal metabolism, and growth, to date, there is no published information on molecular mechanisms behind these events. Hereby, we determined that OC kappa changed the redox status to a more reducing condition favoring an increase of photosynthesis, nutrients assimilation, basal metabolism, and growth. In addition, it is possible to imagine that OC kappa binds to a specific receptor located in the plasma membrane, inducing signal transduction and the activation of a master protein capable of regulating basal metabolism and photosynthesis. Such a master protein could correspond to the kinase Target of Rapamycin (TOR), a major regulator of nutrient assimilation and basal metabolism in humans, yeast, and plants (Xiong and Sheen, 2014). However, the potential involvement of TOR in the activation of nutrient assimilation and basal metabolism in Eucalyptus trees treated with OC kappa remains to be determined.

\section{CONCLUSIONS}

In this work, we showed that: (i) OC kappa induced an increase in NADPH, ASC, and GSH syntheses changing the redox status to a more reducing condition, (ii) the increase in $\mathrm{NADPH}$, ASC, and GSH synthesis and TRR/TRX activities are cross-talking events (iii) the increase in NADPH synthesis activate TRR/TRX system, and (iv) the increase in NADPH, ASC, and GSH syntheses and TRR/TRX activities determine, at least in part, the increase in photosynthesis, basal metabolism and growth induced by OC kappa in Eucalyptus trees.

\section{ACKNOWLEDGMENTS}

This work was financed by Sirius Natura S. A. and VRIDEI-USACH.

\section{SUPPLEMENTARY MATERIAL}

The Supplementary Material for this article can be found online at: http://www.frontiersin.org/journal/10.3389/fpls.2014.00512/ abstract

\section{REFERENCES}

Alhagdow, M., Mounet, F., Gilbert, L., Nunes-Nesi, A., Garcia, V., Just, D., et al. (2007). Silencing of the mitochondrial ascorbate synthesizing enzyme Lgalactono- 1,4- lactone dehydrogenase affects plant and fruit development in tomato. Plant Physiol. 145, 1408-1142. doi: 10.1104/pp.107.106500

Arnér, E. S., and Holmgren, A. (2001). Measurement of thioredoxin and thioredoxin reductase. Curr. Protoc. Toxicol. Chapter 7, unit 7.4. doi: 10.1002/ 0471140856.tx0704s05

Arrigoni, O., Pacciolla, C., and De Gara, L. (1996). Inhibition of galactonolactone dehydrogenase activity by lycorine. Boll. Soc. Ital. Biol. Sper. 72, 37-43.

Barbosa, J. M., Singh, N. K., Cherry, J. H., and Locy, R. D. (2010). Nitrate uptake and utilization is modulated by exogenous $\gamma$-aminobutiric acid in 
Arabidopsis thaliana seedlings. Plant Physiol. Biochem. 48, 443-450. doi: 10.1016/j.plaphy.2010.01.020

Bashandi, T., Guilleminot, J., Vernoux, T., Caparros-Ruiz, D., Ljung, K., Meyer, Y., et al. (2010). Interplay between the NADP-linked thioredoxin and glutathione systems in Arabidopsis auxin signaling. Plant Cell 22, 376-391. doi: 10.1105/tpc.109.071225

Brugidou, C., Rocher, A., Giraud, E., Lelong, B., Marin, B., and Rainbault, M. (1991). A new high performance liquid chromatography technique for separation and determination adenylic and nicotinamide nucleotides in Lactobacillus plantarum. Biotechnol. Tech. 5, 475-478. doi: 10.1007/BF00155497

Brychkova, G., Yarmolinsky, D., and Sagi, M. (2012). Kinetic assays for determining in vitro APS reductase activity in plant without the use of radioactive substances. Plant Cell Physiol. 53, 1648-1658. doi: 10.1093/pcp/pcs091

Cairns, N. G., Pasternak, M., Wachter, A., Cobbett, C. S., and Meyer, A. J. (2006). Maturation of Arabidopisis seeds is dependent on glutathione biosynthesis within the embryo. Plant Physiol. 141, 446-455. doi: 10.1104/pp.106.077982

Castro, J., Vera, J., González, A., and Moenne, A. (2012). Oligo-carrageenans stimulate growth by enhancing photosynthesis, basal metabolism and cell cycle in tobacco plants (var. Burley). J. Plant Growth Regul. 31, 173-185. doi: 10.1007/s00344-011-9229-5

Delumeau, O., Renard, M., and Montrichard, F. (2000). Characterization and possible redox regulation of the purified calmodulin-dependent NAD+ kinase from Lycopersicon pimpinellifolium. Plant Cell Environ. 23, 1267-1273. doi: 10.1046/j.1365-3040.2000.00636.x

De Pinto, M. C., Francis, D., and De Gara, L. (1999). The redox state of ascorbatedehydroascorbate pair as a specific sensor of cell division in tobacco BY-2 cells. Protoplasma 209, 90-97.

Dominguez-Solis, J. R., He, Z., Lima, A., Ting, J., Buchanan, B. B., and Luan, S. (2008). A cyclophilin links redox and light signals to cysteine biosynthesis and stress responses in chloroplasts. Proc. Natl. Acad. Sci. U.S.A. 105, 16386-16391. doi: 10.1073/pnas.0808204105

Dowdle, J., Ishikawa, T., Gatzek, S., Rolinski, S., and Sminorff, N. (2007). Two genes in Arabidopsis thaliana encoding GDP-L-galactose phosphorylase are requires for ascorbate biosynthesis and seedling viability. Plant J. 52, 673-689. doi: 10.1111/j.1365-313X.2007.03266.x

Foyer, C. H., and Noctor, G. (2011). Ascorbate and glutathione: the heart of the redox hub. Plant Physiol. 155, 2-18. doi: 10.1104/pp.110.167569

García-Ferris, C., and Moreno, J. (1993). Redox regulation of enzymatic activity and proteolytic and susceptibility of ribulose-1,5-bisphosphate carboxylase/oxygenase from Euglena gracilis. Photosynth. Res. 35, 55-66. doi: 10.1007/BF02185411

Gelhaye, E., Rouhier, N., Navrot, N., and Jacquot, J. P. (2005). The plant thioredoxin system. Cell. Mol. Life Sci. 62, 24-35. doi: 10.1007/s00018-004-4296-4

González, A., Castro, J., Vera, J., and Moenne, A. (2013a). Seaweed oligosaccharides stimulate growth by enhancing photosynthesis, carbon and nitrogen assimilation, basal metabolism and cell division. J. Plant Growth Regul. 32, 443-448. doi: 10.1007/s00344-012-9309-1

González, A., Contreras, R. A., and Moenne, A. (2013b). Oligo-carrageenans enhance growth and contents of cellulose, essential oils and polyphenolic compounds in Eucalyptus globulus trees. Molecules 18, 8740-8751. doi: 10.3390/molecules 18088740

Griffith, O. W., and Meister, A. (1979). Potent and specific inhibition of glutathione synthesis by buthionine sulfoximine (S-n-butyl homocysteine sulfoximine). J. Biol. Chem. 254, 7558-7560.

Gromer, S., Arscott, L. D., Williams, C. H., Shirmer, R. H., and Becker, K. (1998). Human placenta thioredoxin reductase: isolation of the selenoenzyme, steady sate kinetics, and inhibition by therapeutic gold compounds. J. Biol. Chem. 273, 20096-20101. doi: 10.1074/jbc.273.32.20096

Hägglund, P., Bunkenborg, J., Maeda, K., and Svensson, B. (2008). Identificaction of thioredoxin disulfide targets using a quantitative proteomics approach based on isotope coded affinity tags. J. Proteome Res. 7, 5270-5276. doi: 10.1021/pr800633y

Hashida, S., Takahashi, H., Kawai-Yamada, M., and Uchimiya, H. (2007). Arabidopsis thaliana nicotinate/nicotinamide mononucleotide adenylyl transferase (AtNMNAT) is required for pollen tube growth. Plant J. 49, 694-703. doi: 10.1111/j.1365-313X.2006.02989.x

Hashida, S., Takahashi, H., and Uchimiya, H. (2009). The role f NAD biosynthesis in plant development and stress responses. Ann. Bot. 103, 819-824. doi: 10.1093/aob/mcp019
Jiang, Y. P., Huang, L. F., Cheng, F., Zhou, Y. H., Xia, X. J., Mao, W. H., et al. (2012). Cellular glutathione redox homeostasis plays an important role in the brassinosteroid-induced increase in $\mathrm{CO}_{2}$ assimilation in Cucumis sativa. New Phytol. 194, 932-943. doi: 10.1111/j.1469-8137.2012.04111.x

Kopriva, S., Muheim, R., Koprivova, A., Trachsel, N., Catalano, C., Suster, M., et al. (1999). Light regulation of assimilatory sulfate reduction in Arabidopsis thaliana. Plant J. 20, 37-44. doi: 10.1046/j.1365-313X.1999.00573.x

Kopriva, S., Suter, M., Von Ballmoos, O., Hesse, H., Krähenbühl, U., Rennenberg, H., et al. (2002). Interaction of sulfate metabolism with carbon/nitrogen metabolism in Lemna minor. Plant Physiol. 130, 1406-1413. doi: 10.1104/pp.007773

Kraiser, T., De Gras, A. G., Gutiérrez, G., González, B., and Gutiérrez, R. A. (2011). Holistic view of nitrogen acquisition in plants. J. Exp. Bot. 62, 1455-1466. doi: 10.1093/jxb/erq425

Lemaire, S. D., Guillon, B., Le Maréchal, P., Keryer, E., Miginiac-Maslow, M., and Decottignies, P. (2004). New thioredoxin targets in the unicellular photosynthetic eukaryote Chlamydomonas reinhardtii. Proc. Natl. Acad. Sci. U.S.A. 101, 7475-7480. doi: 10.1073/pnas.0402221101

Lilley, R. M., and Walker, D. A. (1974). An improved spectrophotometric assay for ribulosebiphosphate carboxylase. Biochim. Biophys. Acta 358, 226-229. doi: 10.1016/0005-2744(74)90274-5

Lillo, C. (2008). Signaling cascades integrating light-enhanced nitrate metabolism. Biochem. J. 415, 11-19. doi: 10.1042/BJ20081115

Lindhal, M., and Florencio, F. J. (2003). Thioredoxin-linked processes in cyanobacteria are as numerous as in chloroplasts, but target are different. Proc. Nac. Acad. Sci. U.S.A. 100, 16107-16112. doi: 10.1073/pnas.2534397100

Liso, R., Innocenti, A. M., Bitonti, M. B., and Arrigoni, O. (1988). Ascorbic acidinduced progression of quiescent center cells from G1 to S phase. New Phytol. $110,469-471$.

Lunn, J. E., Droux, M., Martin, J., and Douce, R. (1990). Localization of ATP sulfurylase and O-acetylserine(thiol)lyase in spinach leaves. Plant Physiol. 94, 1345-1352. doi: 10.1104/pp.94.3.1345

Luo, T., Fan, T., Liu, Y., Rothbart, M., Yu, J., Zhou, S., et al. (2012). Thioredoxin redox regulates ATPase activity of magnesium chelatase CHLI-subunit and modulates redox-mediated signaling in tetrapyrrole biosynthesis and homeostasis of reactive oxygen species in pea plants. Plant Physiol. 159, 118-130. doi: 10.1104/pp.112.195446

Mellado, M., Contreras, R. A., González, A., Dennett, G., and Moenne, A. (2012). Copper-induced synthesis of ascorbate, glutathione and phytochelatins in the marine alga Ulva compressa (Chlorophyta). Plant Physiol. Biochem. 51, 102-108. doi: 10.1016/j.plaphy.2011.10.007

Montrichard, F., Alkhalfioui, F., Yano, H., Vensel, W. H., Hurkman, W. J., and Buchanan, B. B. (2009). Thioredoxin targets in plants: the first 30 years. J. Proteomics 72, 452-474. doi: 10.1016/j.jprot.2008.12.002

Moreno, J., García-Murria, M. J., and Marín-Navarro, J. (2008). Redox modulation of rubisco conformation and activity through its cysteine residues. J. Exp. Bot. 59, 1605-1614. doi: 10.1093/jxb/erm310

Motohashi, K., Kondoh, A., Stumpp, M. T., and Hisabori, T. (2001). Comprehensive survey of proteins targeted by chloroplast thioredoxins. Proc. Natl. Acad. Sci. U.S.A. 98, 11224-11229. doi: 10.1073/pnas.191282098

Muto, S., Miyachi, S., Usuda, H., Edwards, G. E., and Bassham, J. A. (1981). Lightinduced conversion of nicotinamide adenine dinucleotide to nicotinamide adenine dinucleotide phosphate in higher plant leaves. Plant Physiol. 68, 324-328. doi: $10.1104 /$ pp.68.2.324

Née, G., Zaffagnini, N., Trost, P., and Issakidis-Bourget, E. (2009). Redox regulation of chloroplastic glucose-6-phosphate dehydrogenase: a new role for $f$-type thioredoxin. FEBS Lett. 583, 827-2832. doi: 10.1016/j.febslet.2009.07.035

Olessen, U. H., Petersen, J. G., Garten, A., Kiess, W., Yoshino, J., Imai, S. I., et al. (2010). Target enzyme mutations are the molecular basis for resistance toward pharmacological inhibition of nicotinamide phosphoribosyltransferase. BMC Cancer 10:677. doi: 10.1186/1471-2407-10-677

Olmos, E., Kiddle, J., Pellny, T. K., Kumar, S., and Foyer, C. H. (2006). Modulation of plant morphology, root architecture, and cell structure by low vitamin $\mathrm{C}$ in Arabidopsis thaliana. J. Exp. Bot. 57, 1645-1655. doi: 10.1093/jxb/erl010

Ratkevicius, N., Correa, J. A., and Moenne, A. (2003). Copper accumulation, synthesis of ascorbate and activation of ascorbate peroxidase in Enteromorpha compressa (L.) Grev. (Chlorophyta) from heavy-metal enriched environments in northern Chile. Plant Cell Environ. 26, 1599-1608. doi: 10.1046/j.13653040.2003.01073.x 
Shigeoka, S., Ishikawa, M., Tamoi, M., Miyagawa, Y., Takeda, T., Yabuta, Y., et al. (2002). Regulation and function of ascorbate peroxidase isoenzymes. J. Exp. Bot. 53, 1305-1319. doi: 10.1093/jexbot/53.372.1305

Ströher, E., and Dietz, K. J. (2008). The dynamic thiol-disulfide redox proteome of the Arabidopsis thaliana chloroplast as revealed by differential electrophoretic mobility. Physiol. Plant. 133, 566-583. doi: 10.1111/j.1399-3054.2008.01103.x

Sweetlove, L. J., Heazlewood, J. L., Holzapffel, H., Day, D. A., Leaver, C. J., and Millar, A. H. (2002). The impact of oxidative stress in plant mitochondria. Plant J. 32, 891-904. doi: 10.1046/j.1365-313X.2002.01474.x

Takahashi, H., Kopriva, S., Giordano, M., Saito, H., and Hell, R. (2011). Sulfur assimilation in photosynthetic organisms: molecular functions and regulation of transporter and assimilatory enzymes. Annu. Rev. Plant Biol. 62, 157-164. doi: 10.1146/annurev-arplant-042110-103921

Tischner, R., and Schmidt, A. (1982). A thioredoxin-mediated activation of glutamine synthetase and glutamate synthase in synchronous Chlorella sorokiniana. Plant Physiol. 70, 113-116. doi: 10.1104/pp.70.1.113

Valpuesta, V., and Botella, M. A. (2004). Biosynthesis of L-ascorbic acid in plants: new pathways for an old antioxidant. Trends Plant Sci. 9, 573-577. doi: 10.1016/j.tplants.2004.10.002

Vauclaire, P., Kopriva, S., Feld, D., Suter, M., Sticher, L., von Ballmoos, O., et al. (2002). Flux control of sulfate assimilation in Arabidopsis thaliana: adenosine $5^{\prime}$ phosphosulfate reductase is more susceptible to negative control by thiols than ATP sulfurylase. Plant J. 31, 729-740. doi: 10.1046/j.1365-313X.2002.01391.x

Veljovic-Jovanovic, S. D., Pignocchi, C., Noctor, G., and Foyer, C. H. (2001). Low ascorbic acid in the vtc-1 mutant in Arabidopsis is associated with decreased growth and intracellular redistribution of the antioxidant system. Plant Physiol. 127, 426-435. doi: 10.1104/pp.010141

Vera, J., Castro, J., González, A., and Moenne, A. (2011). Seaweed polysaccharides and derived oligosaccharides stimulate defense responses and protection against pathogens in plants. Mar. Drugs 9, 2514-2525. doi: 10.3390/md9122514

Vernoux, T., Wilson, R. C., Seeley, K. A., Reichheld, J. P., Muroy, S., Brown, S., et al. (2000). The ROOT MERISTEMLESS1/CADMIUM SENSITIVE2 gene defines a glutathione-dependent pathway involved in initiation and maintenance of cell division during postembryonic root development. Plant Cell 12, 97-108. doi: 10.1105/tpc.12.1.97
Wang, P., Liu, J., Liu, B., Feng, D., Da, Q., Shu, S., et al. (2013). Evidence for a role of chloroplastic m-type thioredoxins in the biogenesis of photosystem II in Arabidopsis. Plant Physiol. 163, 1710-1728. doi: 10.1104/pp.113. 228353

Xiong, Y., and Sheen, J. (2014). The role of target of rapamycin signaling networks in plant growth and metabolism. Plant Physiol. 164, 499-512. doi: 10.1104/pp.113.229948

Yamazaki, D., Motohashi, K., Kasama, T., Hara, Y., and Hisabori, T. (2004). Target proteins of the cytosolic thioredoxins in Arabidopsis thaliana. Plant Cell Physiol. 45, 18-27. doi: 10.1093/pcp/pch019

Zar, J. (1999). Biostatistical Analysis. Englewood Cliffs, NJ: Prentice Hall.

Zhang, N., and Portis, A. R. (1999). Mechanism of light regulation of rubisco: a specific role of the larger rubisco activase isoform involving reductive activation by thioredoxin-f. Proc. Natl. Acad. Sci. U.S.A. 96, 9438-9443. doi: 10.1073/pnas.96.16.9438

Conflict of Interest Statement: The authors declare that the research was conducted in the absence of any commercial or financial relationships that could be construed as a potential conflict of interest.

Received: 08 April 2014; accepted: 12 September 2014; published online: 13 October 2014.

Citation: González A, Moenne F, Gómez M, Sáez CA, Contreras RA and Moenne A (2014) Oligo-carrageenan kappa increases NADPH, ascorbate and glutathione syntheses and TRR/TRX activities enhancing photosynthesis, basal metabolism, and growth in Eucalyptus trees. Front. Plant Sci. 5:512. doi: 10.3389/fpls.2014.00512

This article was submitted to Plant Biotechnology, a section of the journal Frontiers in Plant Science.

Copyright (c) 2014 González, Moenne, Gómez, Sáez, Contreras and Moenne. This is an open-access article distributed under the terms of the Creative Commons Attribution License (CC BY). The use, distribution or reproduction in other forums is permitted, provided the original author(s) or licensor are credited and that the original publication in this journal is cited, in accordance with accepted academic practice. No use, distribution or reproduction is permitted which does not comply with these terms. 